\title{
SUSRET PSIHOTERAPIJA ISTOKA I ZAPADA
}

U radu se diskutuju kreativni izazovi sa kojima se susreće psihoterapija kao nova profesija u novom milenijumu. Koncept ega i dva tipa svesnosti su ključni u razmatranju različitosti psihoterapijskog pristupa Istoka i Zapada u pogledu lekovitosti terapijskog odnosa. Koncept duhovnosti, takođe. Razmatraju se i različiti ciljevi koji se postavljaju u psihoterapijskom tretmanu, a koji nužno vode i do različitih ishoda. Ostaje pitanje: da li je stvarno susret različitih pristupa Istoka i Zapada moguć, i ,ako jeste, kako se najbolje može ostvariti njihova saradnja.

Ključne reči: Psihoterapija Istoka i Zapada, ego, ego-svesnost, svesnost bez ega, duhovnost, susret različitih kulturnih tradicija

\section{UVOD}

Sva dosadašnja otkrića psihologije, posebno psihoterapije, sledeći delfijski savet “upoznaj samog sebe!" dragocena su i, neosporno, potrebna čoveku. Neophodnost ove istine, potekle od grčkih filozofa (Sokrata) postoji trajno u čoveku - tragaocu za istinom u svim kulturama i religijama sveta. Međutim, stojimo upitani pred tajanstvenom, skoro neverovatnom za savremenog čoveka, porukom svetog Isaka Sirina: "Ko se udostojio da ugleda samog sebe, viši je od onoga ko se udostojio videti Anđele". Otkuda toliko čovekovo čuđenje pred ovim rečima? Zar je upoznavanje, pa i poznavanje sebe zaista toliko teško? Paradoks ljudskog bića i njegovog postojanja u svetu je u tome što je čovek jedino prirodno biće koje je natprirodno obdareno razumom i slobodom, a u isto vreme je najnezaštićenije biće u prirodi, sa svešću o svojoj prolaznosti, propadljivosti i tragičnosti smrti. Prometejeva gordost, koji svojom hrabrošću, prkosom i trpljenjem odoleva sudbini i nužnosti postojanja, je način da se čovek odbrani od ove unutrašnje razdiruće slabosti. Setimo se da je gordost jedan od najvećih ljudskih grehova. Naravno, postoji još delotvorniji način, odbrana, a to je - 
da čovek uopšte i ne upozna sebe. Podsetimo se samo Tiresijinog proročanstva koje glasi: "Narcis će doživeti duboku starost pod uslovom da ne upozna sebe".

Za upoznavanje sebe čovek mora steći hrabrost, dublju, veću i plemenitiju od one koja je hrabrost ratnika, da siđe u nepoznate dubine sopstvene duše, svog bića. Stekavši jednom ovakvu hrabrost, čovek taj večni tragalac za smislom polazi u večnu, nikad završenu, avanturu čoveka-tragaoca, prema arhetipskom obrascu koji je, po Jungu, prisutan u dubinama psihe svakog pojedinca.

Bilo da mračne dubine ljudske duše poredimo sa lavirintom (kao u grčkoj mitologiji), ili sa hodnicima i pećinama podzemlja, nije moguće krenuti u lavirint bez Arijadninog konca ili svetiljke koja će nam osvetliti put. Šta je zapravo Arijadnin konac ili svetiljka koja će nam osvetliti put, do vera, nada i ljubav, ovo troje, "ali je ljubav najveća među njima" (1 Kor.13.13).

U istraživanjima odnosa psihoterapije Istoka i Zapada, posebno pronalaženja mogućnosti njihovog približavanja, ključni je koncept duhovnosti. Moje osnovno polazište je da se ljudsko i duhovno prepliću i da biti duhovan znači biti/postati human, 'voleti druge kao samoga sebe', biti uistinu saosećajan i solidaran.

Ako ne otvorimo srce ljudskim bićima, ako ne volimo ljude, uključujući tu i sebe, biće nam teško da volimo Boga. U tom smislu naš duhovni put počinje našom ljudskošću.

Pokazuje se istinitost reči jednog sufija koji je rekao: "Tragao sam za Bogom i našao sebe. Tragao sam za sobom i našao Boga".

Zašto je baš danas od presudne važnosti uspostavljanje duhovnosti kao puta koji vodi preporodu ljudi, ali i preporodu psihoterapije koja kao profesija ima pretenzije da pomaže ljudima u njihovoj potrazi za samima sobom. Jasno je već iz brojnih naslova i poplave psihološke literature koja ukazuje na 'ispražnjenost selfa' i 'pustinju' izolacije u kojoj živi pojedinac na Zapadu, daleko od drugih, čak i od sebe sama, ne prepoznajući svoj vlastiti odraz na površini događanja reke života, stranac u svetu, ali i u vlastitoj kući i pred samim sobom.

Ključno pitanje "ko sam ja?" ostaje bez odgovora, jer je i ono ‘ja' dovedeno u pitanje. Možda je upravo ovaj trenutak onaj pravi da se nastavi traganje i da odgovor na postavljeno pitanje dođe kao olakšanje ili prosvetljenje.

Duhovne prakse Istoka pobuđuju sve življe interesovanje na Zapadu i to nije slučajno. Savremeni čovek, u potrazi za sobom, ne može da izađe iz lavirinta svoga 
ega, i on traži izlaz, a taj izlaz je iskorak ka drugome, ka duhovnosti (humanosti), izlazak iz samonametnute mu izolacije i to je u celini izazov njegovog razvoja - od psihološkog ka duhovnom.

Istočnjačke prakse mogu biti od pomoći, ali ih valja razumeti dublje u kontekstu njihovih filozofskih, psiholoških i kulturnih tradicija. Bez njihovog dubljeg razumevanja ne mogu ni biti delotvorne.

\section{PSIHOTERAPIJA ZAPADA}

U savremenoj psihoterapiji su se dogodile krucijalne promene koje uključuju, pre svega, nastajanje psihoterapije kao nezavisne profesije. Prvi fakultet sa studijama psihoterapije (Sigmund Freud University) osnovan je u Beču 2004. i njegov osnivač je Alfred Pritz rektor ovog fakulteta. On je predsednik Svetskog saveta za psihoterapiju (WCP), kao i generalni sekretar Evropskog udruženja za psihoterapiju (EAP) i glavni inicijator za otvaranje psihotearpijskih studija širom Evrope i sveta. To iziskuje i promenu definicije psihoterapije kao discipline različite od psihologije, psihijatrije kao i drugih srodnih disciplina, tzv. 'pomažućih profesija' (helping professions). Kao što već znamo, psihoterapija se bavi promenom ličnosti i/ili ponašanja. Ciljevi psihoterapije danas su (za razliku od prošlog veka kada su većinom bili patocentrični i sledili medicinski model) okrenuti pozitivnom mentalnom zdravlju, sreći i blagostanju (wellbeing). Sve više je zdravlje u žiži interesovanja pozitivne psihologije i psihoterapije.

Za razliku od psihoterapije koja se bavi onim što je zajedničko ljudima (čovekovim izvornim, suštinskim potrebama i željama), psihologija se bavi individualnim razlikama, ona je zapravo nauka individualnih razlika; isto to je i psihijatrija, samo što prva proučava više normalnost, zdravlje, i zdravu psihu (izuzetak je klinička psihologija), dok druga se bavi više bolešću i bolesnom psihom. Postavljanje dijagnoze o zdravlju il' bolesti svakako su prioriteti obe: i psihologije i psihijatrije, dok se psihoterapija bavi promenom.

Ukratko, kao što smo već rekli, psihoterapija se najviše bavi univerzalnom ljudskom psihom (onim što je zajedničko svim ljudima, a to je: da žele da budu srećni i ne žele da pate, kako je to lepo i tačno rekao Dalaj Lama, (1999) i po tome je sasvim različita od prethodnih disciplina.

Kada se usredsredimo na psihoterapiju kao novu naučnu disciplinu, možemo 
konstatovati da je psihoterapija definisana i određena višestruko, različitim domenima, a što se i u nenom razvoju, istorijski, može videti, i to:

(1) Intrapersonalno - u smislu poboljšanja komunikacije sa samim sobom. To znači, pre svega, osvešćivanje svega što je bilo u nesvesnom (prema čuvenoj Frojdovoj zamisli: «Tamo gde je Id, neka bude Ego»). Niče je to lepo izrazio rečima da svaki napredak je napredak u pravcu svesnosti i da nazadak zapravo znaći (po)tonuće u nesvesno. Naša realizacija preko psihoterapije pomaže nam da se oslobodimo balasta prošlosti, svega što je skriveno u senci - nepoznato, neželjeno, neintegrisano; pomaže nam da integrišemo sebe, da postanemo celoviti, što je u krajnjem slučaju zadatak psihoterapije i procesa individuacije o kom je Jung govorio. Jedan od prvih koraka u pravcu izlečenja i leka za to je samo-realizacija. Bez nje mi smo 'osuđeni' da ponavljamo prošlost u terminima sadašnjosti (repetitia compulsia).

(2) Interpersonalno - u smislu poboljšanja komunikacije sa drugima na mikro i makro planu, što znači u relaciji sa našim prijateljima, partnerima, saradnicima, i, uopšte, sa svetom. Frojdova psihoanaliza je bila 'neosetljiva' za socijalne probleme i, kako je poznati psihoanalitičar, Goldberg tačno primetio u svojoj kritici, «psihoanaliza bi trebalo da se okrene prema krucijalnim društvenim socijalnim i moralnim problemima» (Goldberg, 1999, str.335). Čak i više od toga, po Goldbergu, psihoanaliza mora da postane psihoterapija nade, milosrđa i odgovornosti (str.335). Po mom mišljenju, ova Goldbergova opaska mogla bi se odnositi na psihoterapiju uopšte.

(3) Transpersonalno - $u$ smislu uspostavljanja komunikacije sa transcendentnim (Bog) ili preko realizacije najviših ljudskih vrednosti i aspiracija - univerzalnih, koje se odnose na to da se bude human i moralan. To je duhovni nivo na kome tek treba da nastane 'mi - psihologija' i na kome realizacija čoveka kao humanog bića jedino može biti moguća (Milenković, 1997; Milenković, 2002)

Uz proširenje i promenu same definicije psihoterapije valja reći da već krajem prošlog veka su se mogle zapaziti sve brojniji zahtevi da psihoterapija 21 . veka mora pronaći ravnotežu između efikasnosti i humanosti (Vann J, 1998; Goldberg, C, 1999). Nije više dovoljan zahtev za njenom efikasnošću, kao i naučnošću, 
važno je da se ona sprovodi humano. Potrebne su nam najbolje tehnologije, naučne metode i tehnike, ali je potrebno primeniti ih humano - sa saosećajnošću, razumevanjem i strpljenjem.

Drugi zahtev upućen psihoterapiji i psihoterapeutima jeste da je potrebno da se psihoterapija pozabavi više socijalnim problemima, ne samo individualnim, kako je započela svoj put od otkrića psihoanalize do danas.

Ona (psihoterapija) u 21. veku mora biti u stanju da se bavi individualnom dinamikom, kao i da bude proaktivna u restrukturiranju društva koje valja da promoviše ono što je uistinu vredno i značajno u ljudskom životu.

Da bismo bili/postali zaista autonomni i odgovorni članovi društva, verujem da svi moramo potražiti i pronaći načine da intervenišemo efikasno u promociji zdravih obrazaca ponašanja u društvu, kao i da konfrontiramo disfunkcionalne društvene obrasce i ponašanja.

$\mathrm{Na}$ žalost, oruđe koje imamo u rukama kao psihoterapeuti se retko koristi na socijalnom nivou ili ne bar u pozitivne svrhe usmerene rastu i razvoju pojedinca i društva u celini.

Možemo konstatovati da imamo poteškoću da proširimo moralnost za koju koju se zalažemo na individualnom nivou na društveni nivo. Potrebna nam je politička moć da na odgovarajući način ograničimo disfunkcionalno društveno ponašanje. Potrebno je da se pojedinci organizuju politički da bi mogli da imaju uticaja na društvena zbivanja. U tom smislu Endrju Samjuels, (1996), engleski socijalni psiholog, govori o stvaranju 'političke psihe'. Psihoterapeuti, po njemu, u 21. veku treba da postanu više politički nastrojeni (da razviju, kako je on zove, 'političku psihu') zauzimanjem stava u odnosu na to šta je moralno, a šta nije. Kao odgovorni psihoterapeuti, potrebno nam je da pronađemo načine da stečene informacije $i$ veštine učinimo primenljivim na socijalnom nivou $i$ da ne zaboravimo na 'psihopolitičku dimenziju' psihoterapije. (Wilkinson, H., 1996; Vann, J., 1998; Moiso, C., 1998). Alternativa je auto-destruktivna - da se ponašamo i dalje kao autsajderi u svetu koji postaje sve više svet nasilja i destrukcije.

To će biti moguće tek kada prepoznamo i suočimo se sa nepredvidivošću života, prihvatajući našu vulnerabilnost običnih ljudskih bića i veru i hrabrost da živimo puno uprkos svim nepredvidivostima, tada tek možemo uistinu biti 
slobodni.

\section{PSIHOTERAPIJA ISTOKA}

Da bismo bolje razumeli psihoterapiju Istoka, daću kraći pregled koji se tiče istočnjačke koncepcije čoveka i sveta, a koja je u osnovi i psihologije i psihoterapije Istoka. U psihoterapiji mi se bavimo ljudima čiji poremećaj potiče od onoga što je označeno kao «maya», da upotrebim hindu-budističku reč čije značenje je otprilike «iluzija», ali celokupan svet - koncepcija kulture može se posmatrati kao iluzija.

Cilj oslobođenja nije destrukcija ove iluzije - «maya», već njeno proziranje - 'viđenje kroz', viđenje onoga što stoji kao prava realnost iza toga. Igru ne treba uzimati ozbiljno ili, drugim rečima, ideja sveta i ideje koje imamo o sebi su socijalne konvencije/konstrukcije i njih ne treba mešati sa realnošću. (Najveći uticaj ovih istočnjačkih ideja na Zapadu možemo videti kod terapeuta socijalnih konstrukcionista, poput Kenneta Gergena, npr.).

«Maya» ili nerealnost postoji ne u fizičkom svetu, već u konceptualnim i misaonim formama kojima se on opisuje. Jasno je, stoga, da se «maya» odnosi na socijalne institucije i na način na koji one modifikuju naš doživljaj sveta (Watts, 1960).

Čovek nije uloga ili identitet koji mu društvo dodeljuje i određuje. I tek kada čovek više ne poistovećuje sebe sa definicijom sebe koju su mu drugi dali, on odjednom postaje jedinstven i univerzalan.

Postoje brojni razlozi zašto poremećaj dolazi od ove socijalne pometnje «maya» sa realnošću. Postoji direktan konflikt između toga šta je pojedinac i šta drugi kažu ili očekuju da on bude. Pravila socijalne komunikacije često sadrže kontradikcije koje vode nemogućim dilemama u mišljenju, osećanjima i akciji. Ili, to može biti konfuzija i poistovećivanje sebe sa ograničenim i osiromašujućim pogledom nečije uloge ili identiteta, što stvara osećanje izolacije, usamljenosti i alijenacije.

Kao i egzistencijalisti, budisti (čije učenje je u osnovama psihoterapije Istoka) započinju sa dijagnozom ljudskog stanja.

Prva plemenita istina budizma jeste da je život bolan i ispunjen patnjom. Značenje sanskritske reči $d u k h a$ (konflikt) nije daleko od egzistencijalne anksioznosti.

Konflikt (dukha) nastaje iz pohlepnog grabljenja stvari/entiteta koji su izolovani (izdvojeni) iz sveta, zahvaljujući neznanju (avidya); to stavlja u pogon 
(pokreće) 'samsara' ili začaran krug pokušaja da se reše lažni problemi odvajanja života od smrti, zadovoljstva od bola, dobra od zla i ja(selfa) od ne-ja (ne-selfa), ukratko, da se nečiji ego trajno uzdigne i bude u poziciji iznad života ('one up').

U osnovi svake škole budizma jeste postavka da , ustvari, nema ega, nema ,dakle, tog entiteta koji bi bio stalni subjekt naših promenljivih iskustava (Watts,1962, str. 56).

Ovaj uvid (prajna) donosi 'nirvanu', oslobođenje od lažnih problema. Nirvana je radikalna transformacija: sve se događa samo od sebe, Postoji odluka, izbor, ali ne i doživljaj. «ja to činim». Oni nastaju sami od sebe u odnosu na okolnosti i događanja. Odluka je istovremena sa akcijom (ne reakcijom).

Život više nije doživljen kao susret između subjekta i objekta, već kao polarizovano polje gde kontakt suprotnosti postaje igra suprotnosti.

Lepo poređenje za to je da život izgleda kao čin, ali bez glumca. U budizmu se oslobođenje naziva buđenje (bodhi), upravo zato što je oslobođenje od socijalne hipnoze.

Za budiste ova bol i patnja se mogu izbeći. Bolest se može izlečiti. A da bismo izlečili bolest, moramo najpre identifikovati njen uzrok.

Tako druga plemenita istina budizma jeste da je uzrok (patnje) želja ili vezanost (tanha).Vezanost ega je koren patnje i ispaštanja. Ego je naš najdragoceniji 'posed' i mi smo spremni čak i da patimo samo da ga zaštitimo. Nažalost, ego nije nikada bezbedan.

Pretnje koje su upućene njemu pojavljuju se konstantno i mi moramo neprestano da se nosimo sa anksioznošću. Težimo sigurnosti i pokušavamo da dobijemo što više možemo, akumulirajući stvari (materijalne i nematerijalne). I što više imamo, više se plašimo da ih ne izgubimo. Završavamo, u svakom slučaju, neslavno: umesto sigurnosti, dospevamo i pronalazimo sebe u stanju krajnje nesigurnosti i anksioznosti, čak i panike.

Tako dolazimo i do treće plemenite istine, a ona je da se sve pojave neprestano menjaju, da je sve u kretanju. Ništa nije stalno, niti fiksirano, uprkos našoj potrebi za stalnošću i sigurnošću.

Budistički pogled, takođe, stavlja naglasak na koncept međupovezanosti. Kroz intuitivno razumevanje, međutim, dolazimo do toga da je sve povezano sa svim. Ako su svi fenomeni u međusobnoj vezi, tada ništa i ne postoji nezavisno i ništa ne 
može biti samodovoljno.

Zaključak je da su svi fenomeni, bilo da su to ljudi ili stvari, potpuno prazni što se tiče njihovog postojanja, što znači da ništa i ne postoji tamo negde, nezavisno od posmatrača.

Mi konstruišemo našu realnost. U suštini, naši konstrukti su naša realnost. To je razlog da promenom naših kognicija mi možemo da menjamo realnost u kojoj živimo. (Koliko sličnosti sa konstruktivističkom perspektivom u psihoterapiji koja je vrlo 'na snazi' u ovom trenutku!).

Tekst koji sledi potvrđuje prethodno izrečeno:

"Mi smo ono što mislimo. Sve što smo mi nastaje sa našim mislima. Sa našim mislima mi stvaramo svet» (Crook, Fontana, 1990).

Govinda je rekao: «Dok je u prošlosti sve konačno, rigidno, neizmenljiv zakon, kauzalnost - sadašnjost je življeni odnos koji se da izmeniti, fluidan i nikad finalan. Tako je sadašnjost oslobođenje od kauzalnosti» (Crook, Fontana, 1990).

Mi ukidamo princip kauzalnosti postajući na taj način razuslovljeni/ neuslovljeni i slobodni.

\section{KONCEPT EGA I DVA TIPA SVESNOSTI: EGO-SVESNOST I SVESNOST BEZ EGA}

Naša svest je samo ogledalo. Ogledalo ne čini ništa, ono samo reflektuje događanja u okolini.

Po rečima Čuang-cea, «Savršen čovek koristi svoj um kao ogledalo. Ono ne doživljava ništa; ono ne odbija ništa. Ono prima, ali ne zadržava» (Watts, 1982, str. 28).

Primenjujući ovo na psihoterapeute, možemo reći da se to ne odnosi samo na njih, već i na svest klijenata koji uče od terapeuta kako da žive bez balasta prošlosti (šema, uverenja, predrasuda), kako da to što je u senci iznesu na videlo, dožive u realnosti i oslobođeni produže dalje.

Šta možemo, imajući u vidu psihologiju i psihoterapiju Istoka, da konstatujemo vezano za naš ego i našu svesnost?

(1) Identitet osobe prvenstveno je vezan za ego, za sliku o sebi nastalu učenjem od značajnih drugih koja se stiče učenjem, pre svega uslovljavanjem i 
učenjem po modelu.

(2) Koncept ne-vezanosti (non-attachment-a) kao raz-uslovljenost od različitih oblika uslovljenosti i neslobode, koji sve više biva prihvaćen od strane psihoterapeuta Zapada.

(3) Naš vrhovni identitet je 'bezgranična svest' (Wilber, K, 2002)

(4) Rast i razvoj predstavljaju uvećanje i širenje čovekovih vidika/svesti/granica prema spolja i prema unutra.

(5) Postoje dve vrste svesnosti i to: a) ego-svesnost i b) svesnost bez ega

(6) Ego svesnost je svesnost koja se identifikuje sa mentalnim sadržajima, a koji su ustvari izvor projekcija ili fantazije (coscious ego)

(7) Svesnost bez ega (egoless consciousness) je svesnost bez identifikacija i projekcija. Koncept 'mindfulnessa' već je ušao na vrata koja su širom otvorili KBT-ovci (kognitivno-bihejvioralni terapeuti)

\section{SAMOSPOZNAJA I SAMOODREĐENJE}

A sad mala digresija: o konceptima samospoznaje i samoodređenja bitnim za razumevanje susreta i veze Istoka i Zapada u psihoterapiji.

Samospoznaja je odlučujuća u promeni ličnosti. Da bismo mogli da zavolimo sebe, valja najpre upoznati sebe, a tek onda dolaze naši bližnji i ljubav prema njima.

Termin mindfulness je taj koji najbolje opisuje našu svesnost i to "svesnost od trenutka do trenutka”; "održavanje nečije svesnosti živom u sadašnjoj realnosti” predstavlja engleski prevod pali-termina 'sati' koji označava 'svesnost (awareness); pažnju (attention)' koji su povezani kao odnos figure i pozadine.

Tri bitna elementa definicije su:

(1) svesnost

(2) sadašnjeg doživljaja/trenutka

(3) uz njegovo prihvatanje nezavisno od toga da li je on pozitivan ili negativan

Ova tri elementa mogu se naći u brojnim diskusijama o mindfulness-u kako u budističkoj, tako i u psihoterapijskoj literaturi.

Samoodređenje predstavlja dez-identifikovanje sebe; razuslovljavanje sebe, bilo od negativne, bilo od pozitivne slike o sebi. To je pojam 'prave, autentične čovekove prirode'. 
Da bi postao čovekom, autentičan, razuslovljen od prošlih iskustava, od njega se zahteva da transcendira ono što je dato: svoju biološku i psihološku datost (naučenu "drugu prirodu"), zahteva napor koji on treba da uloži u svoju samodeterminaciju (samoodređenje), kao i radoznalost, strast, hrabrost i strpljenje, toleranciju i upornost. Tek tada možemo biti/postati svesnost koja sebe doživljava u potpunosti prisutnom u sadašnjem trenutku/realnosti uz njeno prihvatanje, bilo ono pozitivno ili negativno.

\section{SUSRET PSIHOTERAPIJA ISTOKA I ZAPADA}
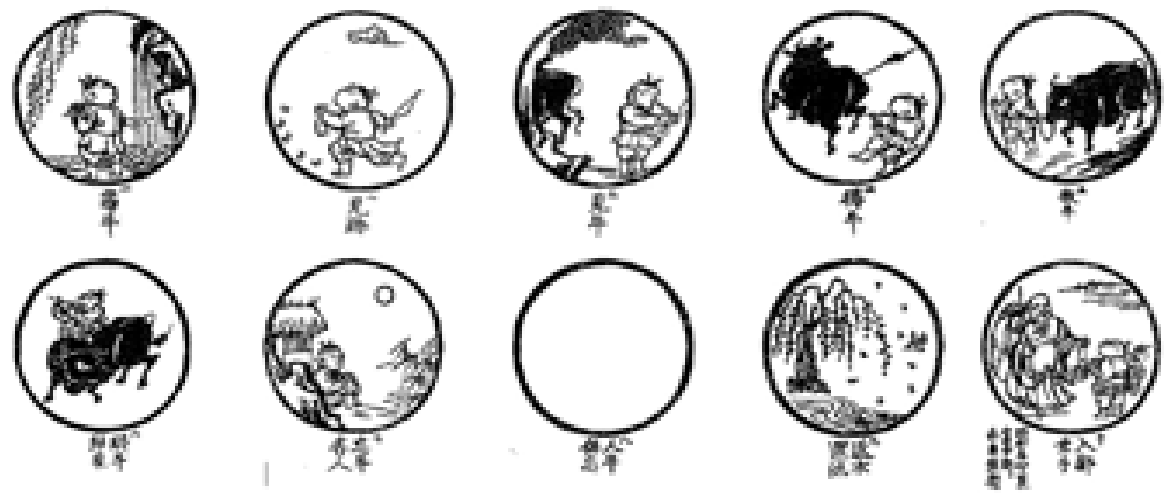

Deset slika o pripitomljavanju bika

Susret psihoterapija Istoka i Zapada najbolje se može sagledati kroz njihove sličnosti, ali i razlike. Najbolja ilustracija za to je metaforična priča o 'pripitomljavanju bika' (Ten Bulls of Zen). Deset slika su slikovne reprezentacije upitnika, a taj upitnik je sam čovek.

Pokušaću ukratko da prikažem suštinu svake od njih i da služeći se njima napravim paralelu između psihoterapije Istoka i Zapada.

Bik predstavlja našu energiju. Ali, najpre, o istorijatu ovih slika.

Ove metaforičke slike prikazuju stupnjeve 'duhovnog školovanja' (Suzuki, 1982). To je kedna od najpopularnijih dalekoistočnih alegorija o putu čovekovog duha prema prosvetljenju (oslobođenju, probuđenju, očišćenju, ostvarenju, i sl.). To je priča kako pastir postupno kroti i pripitomljava nepokornog bika (u nekim drugim 
verzijama slika u pitanju su krave).

Pogledajmo tih deset sleka i prokomentarišimo njihovo značenje uz pomoć slavnog Suzukija koji je u mnogome uspeo da približi mudrost dalekog Istoka zapadnom čitaocu.

Prvobitno, postojalo je samo osam slika, ne deset.i one nisu bile budističke, već taoističke. Ne zna se za njihov početak. Niko ne zna kako su one nastale, ko je naslikao prve slike. Zna se, međutim, da ih je u 12. veku kineski zen majstor, Kakuan, ponovo naslikao. I ne samo to, on je dodao još dve slike, tako da ih je sada bilo deset umesto osam. Taoistička verzija završavala je sa osmom slikom, ona je predstavljala prazan krug - prazninu, ništa. Kakuan je dodao dve nove slike. On je naslikao deset slika celokupne potrage čoveka za samim sobom u kojoj čovek sam perdstavlja to traženje/potragu.

Prva slika je 'u potrazi za bikom'. Zatim, čovek (pastir)' opaža tragove bika' (druga slika). Treća slika je na kojoj pastir 'vidi bika'. 'Bik je uhvaćen' (četvrta slika). 'Bika treba voditi na pašu' (peta slika). 'Vraća se kući, jašući na biku' (šesta slika). 'Bik pada u zaborav a čovek ostaje sam' (sedma slika). 'Bik i čovek nestali iz vidokruga' (osma slika). Slika praznine-praznog kruga. 'Vraćajući se iskonu, uspinje se do izvora' (deveta slika). 'Ulazi u grad, iz ruku mu se širi blagoslov' (deseta slika).

Ako pokušamo da povežemo to što nam slike prikazuju sa terapijskim procesom, prve tri slike odgovaraju razumevanju osnovne dinamike kod klijenta/ pacijenta.

Bik je upravo centralni simbol bazičnih emocija (ili kognicija, u drugačije orijentisanoj psihoterapiji). Najpre postoje negativne emocije i misli koje su u našoj svesti, u žiži našeg interesovanja (zato i dolazimo na psihoterapiju da ih se oslobodima) Hvatanje bika znači da smo postali svesni i da smo to doživeli bez potiskivanja. Od tragova bika, koji su bili tek nagoveštaji onoga što smo želeli da upoznamo kao tamnu stranu sebe, onoga što je bilo u senci (otuda je u nekim verzijama slika bika najpre crna, da bi kasnije on postajao sve više beo, do njegovog totalnog izbeljenja), prego viđenja bika (kada smo 'progledali', umesto da naše interpretacije uzimamo za realnost, koje su nam prethodno izgledale realnije od same realnosti - onakve kakva je), njegovog hvatanja (što znači da smo postali svesni naših negativnih emocija i misli bez potiskivanja), dospeli smo do 'vođenja bika na pašu' ili pripitomljavanja, a to znači da smo uspeli da uspostavimo kontrolu nad impulsima, osećanjima i da 
smo počeli da razrešavamo bazični konflikt. 'Vraćajući se kući, jašući na biku' znači prihvatanje problema i realnosti (izmirenje sa sobom i realnošću). 'Bik pada u zaborav. a čovek ostaje sam' - znači potpuno razrešenje konflikta. Upravo to znači ne-prianjanje (non-attachment attitude) ili prazninu (sunyata).

Kad znaš da ono što ti treba, nije ni zamka ni mreža, nego zec ili šaran, kao da si pročistio zlato od šljake i kao da je mesec izašao iza oblaka (Suzuki, 1982), str. 328). 'Bik i čovek su nestali iz vidokruga' predstavlja potpunu nezavisnost ili prazninu (sunyata). Čitava zbrka je nastala i prevladala je potpuna vedrina. Jer, tamo gde nema nikakvog dualizma, ne može čak ni biće sa hiljadu očiju pronaći pukotinu (str. 329). Ova slika predstavlja upravo onu tačku u kojoj se uspostavlja ta suštinska razlika između puteva oslobođenja koje nudi Istok i puteva (terapijskih) koje nudi Zapad.

'Vraćajući se iskonu, uspinje se do izvora' (deveta slika) predstavlja viđenje sebe i realnosti onakvih kakve jesu ili to predstavlja povratak svojoj (pravoj) prirodi.

'Ulazi u grad, a iz ruku mu se širi blagoslov', označava Bodisatvu koji pomaže drugima, da i oni pređu sličan put (to može oznaćavati i mudrog, zrelog psihoterapeuta, u zapadnom smislu te reči).

Osma slika, prazan krug, kao što sam već napomenula, predstavlja onaj momenat kada nakon razrešenja konflikta dolazi do potpune nevezanosti, razuslovljenosti ili praznine.

U psihoterapiji Zapada mi zahvaljujući postojećim formama psihoterapije menjamo lošu sliku o sebi koju imamo i zbog koje i dolazimo na psihoterapiju, za onu dobru (da smo ok, vredni ljubavi, postajemo 'prinčevi i princeze', itd.), dok u istočnjačkim načinima oslobođenja krajnji cilj jeste upravo taj da ODUSTANEMO, NAPUSTIMO BILO KAKVE SLIKE, KONCEPTE O SEBI, bilo oni negativni ili pozitivni.

U psihoterapijama Zapada, kada čovek dođe do ove tačke kada se oseća bolje (OK), to ne znači da on ne može ići i produžiti i dalje, ali je to njegov individualni poduhvat.

Međutim, psihoterapija Zapada se ovde zaustavlja i ne ide dalje, makar to nije činila do sada. Poslednjih godina se na psihoterapijskoj sceni ipak naziru pokušaji da se uvedu novi koncepti sa Istoka, kao što je onaj koji govori o 'minfulnessu', a to je upravo doticaj praznine (osme slike) koja govori o našoj mogućoj raz-uslovljenosti 
i nevezanosti za sve one socijalne forme uslovljenosti, naše prošlosti, vaspitanja i svega što nam je unapred dato kao 'a priori', 'sveto' i nepromenljivo, koje nam diktira mnošto 'mora' i 'treba' koji se postavljaju pred pojedinca, a koje on valja da sledi.

Nakon što smo razvili naš ego u potpunosti (obično u prvoj polovini našeg života), mi možemo da iskoračimo i idemo dalje, možemo i da ga odbacimo i tu je već iskorak u sferu duhovnosti /humanosti (univerzalnih vrednosti), a što nam omogućava da prevazićemo naše ego-ističke interese i interesovanja, da zavolimo ne samo sebe, već i naše bližnje, kao sami sebe, kako to stoji u bibliji. U stvari, tek je to pravi trenutak za to.

Upravo, mišljenja sam, da hipertrofirani razvitak ega na Zapadu upravo dolazi u fazu kada će takav poduhvat postati moguć i lak poduhvat.

Valja napomenuti da je jedan od pouzdanih kriterijuma da je neko oslobođen/ prosvetljen kada njegovi snovi i realnost postanu jedno (kongruentni).

\section{KONCEPT BODISATVE - ZRELOG PSIHOTERAPEUTA}

U jednoj sutri (Lotus Sutra) stoji zapisano: "Dok postoji i jedna jedina duša koja nije spasena, vratiću se na ovaj svet da joj pomognem"

Kakav je Bodisatva? Da li on može biti model za zrelog psihoterapeuta?

Bodisatva se ne kloni nikakvih patnji ako one mogu makar malo da doprinesu opštem blagostanju i dobrobiti čovečanstva; njegova ljubav je bez granica i bez uslova!

Kako stoji stvar sa psihoterapeutima? Kakvoj/čijoj dobrobiti oni teže?

U seriji istraživanjima na našim i stranim terapeutima (Milenkovič, S. 1992; Milenković, 1996; Milenković, 1997; Milenković, Šakotić, 1997; Milenković, Šakotič, 1998; Šakotić-Kurbalija, Milenković, 2005; Milenković, Šakotić-Kurbalija, 2011; Milenković, Šakotić-Kurbalija, 2012), poslednje u nizu istraživanje koje smo sproveli na temu :šta psihoterapeuti žele, o čemu oni sanjaju/maštaju (Milenković, Šakotić-Kurbalija, 2012) pokazalo je sledeće:

1. Da se naši psihoterapeuti ne razlikuju od evropskih značajno ni u jednom od brojnih istraživanja.

2. Da se psihoterapeuti sve više pomeraju ka duhovnosti, njenoj važnosti za njih u profesionalnom i privatnom životu. 
3. Da su psihoterapeuti najviše zainteresovani za vlastitu dobrobit (100\%)

4. Da se u većoj meri interesuju za svoju profesionalnu dobrobit (približno $80 \%)$

5. Da se u manjoj meri (oko $40 \%$ ) interesuju za svoje klijente i njihovu dobrobit, a

6. Da se najmanje interesuju za dobrobit svih ljudi (manje od 20\%), što je najviše povezano sa njihovom duhovnošću, njihovnim duhovnim rastom i razvojem ličnosti.

Uzorak su činili naši istaknuti terapeuti i terapeuti Evropskog borda za psihoterapiju; to su bili reprezentativni terapeuti - predstavnici različitih modaliteta, udruženja i instituta.

Zaključak koji se nameće jeste da je 'zavoleti svoga bližnjega' još uvek stvar budućnosti. Mi smo tek na početku razvoja duhovne dimenzije ličnosti psihoterapeuta.

Međutim, pravac kretanja razvoja u pravcu duhovnosti odgovara duhu vremena i svim upozorenjima koja dolaze sa raznih strana. Jedno do tih dolazi od strane filozofa i publiciste Anatola Fransa koji kaže da ako 21. vek ne bude vek duhovnosti (on govori o religioznosti), neće ga ni biti.

Što se tiče vlastitog odgovora, kao psihoterapeuta, na pitanje koje se tiče moje profesije: Kakvu psihoterapiju želim i zamišljam u budućnosti, moj odgovor je sledeći:

Želim psihoterapiju koja će mene i moje klijente, studente i edukante povezati sa :

1. Ličnim resursima (mudrošću nesvesnog, intuicijom i bogom koji je u nama);

2. Interpersonalnim resursima (našim bližnjima, zajednicom i svim živim i neživim svetom u celini, planetom - našim globalnim domom);

3. Transpersonalnim resursima (bogom i najvišim, univerzalnim vrednostima - humanošću, pre svega!)

Naš zajednički zadatak jeste da postanemo humana ljudska bića i u tome je najviši smisao duhovnosti. Taj zadatak još nije ostvaren. Kako je Niče lepo i ,pre svega, tačno primetio: "Zapovest o ljubavi prema bližnjem nije se još nikad proširila da obuhvati suseda" (Niče, 1972) 


\section{LITERATURA}

\section{Biblija}

Crook, J., Fontana, D. (1990). Space in Mind. Element Books, Longmead, Dorset.

Dalaj Lama \& Cutler, H. (1999). The Art of Happiness. Coronet Books, Hodder \& Stoughton.

Goldberg, C. (1999).Psychoanalysis and moral apathy; the case of the unpatriotic prostitute. Int. J. Psychotherapy, Vol. 4, No. 3, 329-336.

Milenković, S. (1992). Vrednosne orijentacije savremene psihoterarapije, Doktorska disertacija, Medicinski fakultet, Beograd.

Milenković, S. (1996). Istraživanje vrednosnih orijentacija psihoterapeuta u nas, U: Genz, L. \& Ignjatović, I. (priredili): Ličnost u višekulturnom društvu, Vol. 3, Univerzitet u Novom Sadu, Filozofski fakultet, Odsek za psihologiju, Novi Sad.

Milenković, S. (1997). Vrednosti savremene psihoterapije, Prometej, Novi Sad.

Milenković, S. \& Šakotić, J. (1997). Kako terapeuti shvataju altruizam? Psihijatrija danas, Beograd, 3-4, 351-384.

Milenković, S. \& Šakotić, J. (1998). Moralno rasuđivanje terapeuta u društvu u tranziciji, Psihijatrija danas, Beograd, 30, 1, 49-71.

Milenković, S. (2002). Psihoterapija i duhovnost, Čigoja, Beograd.

Milenković, S. \& Šakotić-Kurbalija, J. (2012). Psychotherapists’ Dreaming: What are the psychotherapists dreaming of?, World J Psychotherapy (in press)

Milenković, S. \& Šakotić-Kurbalija, J. (2011). Psychotherapists and their attitudes toward spirituality, neobjavljen rukopis.

Moiso, C. (1998). Being and Belonging. The Script, Vol. XXVIII, No. 9, Dec.

Niče, F. ( 1972) Volja za moć, Prosveta, Beograd.

Samuels, A. (1996). The politics of transformation/the transformation of politics. Int. J. Psychotherapy, Vol. 1, No. 1, 79-89.

Suzuki, D.T. \& From, E. (1964). Zen budizam i psihoanaliza. Nolit, Beograd.

Šakotić-Kurbalija, J. i Milenković, S. (2005). Evropski identitet psihoterapeuta u Srbiji. u: Franceško, M. i Zotović, M. (priredili): Ličnost u višekulturnom društvu, 
Vol. 5, Univerzitet u Novom Sadu, Filozofski fakultet, Odsek za psihologiju, Novi Sad, str. 50-58.

Vann, J. (1998).Psychotherapy in the 21st Century. The Script, Vol. XXVIII, No.3, April.

Watts, A. (1960).Psychotherapy East and West. Vintage Books, New York.

Watts, A. (1982). Put zena, NIRO “Književne novine”, Beograd.

Wilber, K(2002). Bez granica, Babun, Beograd.

Wilkinson, H. (1996). Psychotherapy at the crossroads, Int. J. Psychotherapy, Vol. 1, No. 1, 5-15.

Snežana Milenković

THE MEETING OF EAST AND WEST PSYCHOTHERAPIES

\section{Summary}

What is discussed here is creative challenge faced by the new profession of psychotherapy in a new millenium. The concept of ego and two kinds of awareness are the key concepts in discussion of diversities of East/West psychotherapy approaches and the healing relationship. The most often asked questions in the entire field of psychotherapy East and West will also be discussed. The rest is the question: Is the meeting between East and West approaches possible and if it is, how the two can cooperate best? 